\title{
"Encounters with Ancient Egypt," Institute of Archae- ology, UCL, 16-18 December 2000
}

\author{
Andrew Munson (16 ${ }^{\text {th }}$ December) \\ Institute of Archaeology. UCL. \\ Geoffrey Tassie ( $17^{\text {th }}$ December) \\ ECHO-Egyptian Cultural Heritage Organisation. \\ Kathryn E. Piquelle (18 $18^{\text {th }}$ December) \\ Institute of Archacology, UCL.
}

The "Encounters with Ancient Egypt" conference took an innovative form. Over 80 papers were available on the Internet weeks in advance and rather than being "read" as at a conventional conference, the main points of each paper would be summarised and illustrated by the 'speakers' during the conference proper. The organisers, John Tair, Dominic Monserrat, and Olivia Forge, were able to draw contributions from leading scholars as well as graduate students and professionals. According to the official announcement, the purpose of the conference was "to examine the ways in which the cultures of Egypt - Predynastic, Dynastic. Hellenistic. Roman, LateAntique, Islanic, Colonial - have pespetually been re-configured in response to changing ideologies and strategies for appropriating the past." This brought together scholars from many fields with different themes and methodologies for studying ancient Egypt. They succeeded in demonstrating the complex and important position of ancient Egypt in modern academic, political, and popular discourse.

\section{6th December}

In the first session, "Egypt as a Source of Awe and/or Inspiration" the chairperson, David Frankfurter, set a difficult precedent by leading a discussion that found points of contact in each paper. Several panel members described the fascination of medieval and modern Arabic, Chinese, and Japanese writers with exotic Egyptian phenomena such as nummification and the pyranids. The extension of Egyptian terms and concepts could even inspire interest in the unrelated 'pyramids' of Meso-America and the Spanish Canary Islands. The inspiration from Egyptian literature and art was evident in several further examples from psychology, architecture, painting, and science. This discussion led to a debate over Orientalism as one audience member criticised Edward Said and his followers for assuming that modern Egyptian culture was completely ignored in Napoleon's Description de l'Égypte, which presented Egypt to many Europeans.

A unique strategy divided the contributors in Saturday's second session, "Egypt in/ and Africa", into pairs for debate and discussion. Martin Bernal was present to argue for his Afro-Asiatic model of the origins of Greek culture. Classical historian John North gave a paper defending recent scholarship from the charge of racist exclusion and questioning the signiticance of attributing colour to ancient Egyptians. However, North conceded to many of Bernal's points in discussion, arguing mainly that classical scholars have anticipated his criticism since the 1970 s and produced many 
good studies on the Near Eastern influences in ancient Greek culture. Another lively debate arose over the archaeological data for Egypt's association with other African cultures. The ideological currents governing the relationship between Egypt and Africa among European and African intellectuals was a major theme for the several contributors on the panel.

Over ten participants made contributions in the session "Egypt in Education". Several papers were devoted to the role of museums and libraries in shaping popular perceptions of ancient Egypt. Discussing the results of questionnaire surveys and drawing from many theoretical approaches, participants examined some of the current problems and strategies in presenting ancient Egypt to the public. The feeling among most museum experts and Egyptologists was that they should attempt to present Egypt to a wider audience by listening to popular demands. Some demonstrated the possibilities for improving teaching and exhibitions with new technology such as virtual reality. Participants from Yugoslavia, Tanzania, and Argentina explored the social and ideological factors behind the inclusion of Egyptology in the school curricula of those countries.

Panel members for the day's final session, "Egypt's View of Itself and Others", were each allotted a few minutes to present ideas with unfortunately little time for discussion. There were two contributions on Egyptian conceptions of history. Kenneth Kitchen discussed the role of official and mortuary records in creating a significant past for later Egyptians. Eric Uphill used mythological literature to determine what concepts an Egyptian might have used to measure time and write about the past. Other contributions focused on burial practices in the earliest period of Egyptian history, including the orientation of burials in Predynastic Egypt and the role of the text in Old Kingdom tombs. The representation of foreigners in Egyptian literature and art was discussed by three panel members. Two focused on the Ptolemaic period specifically while the other surveyed the attitudes toward foreigners in the Pharoanic period. After this final session, all participants were invited to a wine reception at the Petrie Museum of Egyptian Archaeology where debates and discussions continued in a more festive environment.

\section{Decenber}

Most of the second day of the conference was taken up by a tour of London, led by Dominic Montserrat. However, before the tour got underway, there was a series of lectures on "Egyptianising Monuments", in other parts of the world. There were three presentations and papers discussed, chaired by Jean-Marcel Humbert (Musée de la Marine. Paris). The first of these papers was by Cathie Bryan (Wice, Paris) on "Egypt in Paris: $19^{\text {th }}$ Century Monuments and Motifs". The second debate and illustration was by Izak Cornelius (Department of Ancient Studies, University of Stellenbosch, RSA), on "Motifs in South African Architecture and Literature". The final presentation before the tour of London was "Neo-Egyptian Garden Ornaments in Florence during the $19^{\text {th }}$ Century", presented by Gloria Rosati (Università di Firenze, Italy). These papers explored the various Egyptianising components found in Paris, South Africa and Italy, such as sphinxes, pyramids, obelisks, winged sun-discs and papyriform and lotiform columns. It demonstrated the wide appeal of ancient Egypt and the diverse ways in which buildings and landscapes can be Egyptianised. 
The tour of London was conducted in a double-deckicr London bus even though the first stop was the Wellcome Building on Euston Road. situated within easy walking distance from the Institute of Archaeology (UCL). This 1920s building has a classical façade, however, the fanlight ornament is an Aten-disc, with an Eye of Horus at its centre. Travelling a short way North to Mornington Crescent, and the Carreras Building in Hampstead Road, the tour party were trested to one of the most glorious of the Egyptianised buildings in London, one only rivalled in its elegancc by the Hoover Building on the At0 road (sadly not visited).

The Carreras Building, originally built in 1928-9. has recently been restored to its past glory, although not all of its original features have been preserved. and the inte-

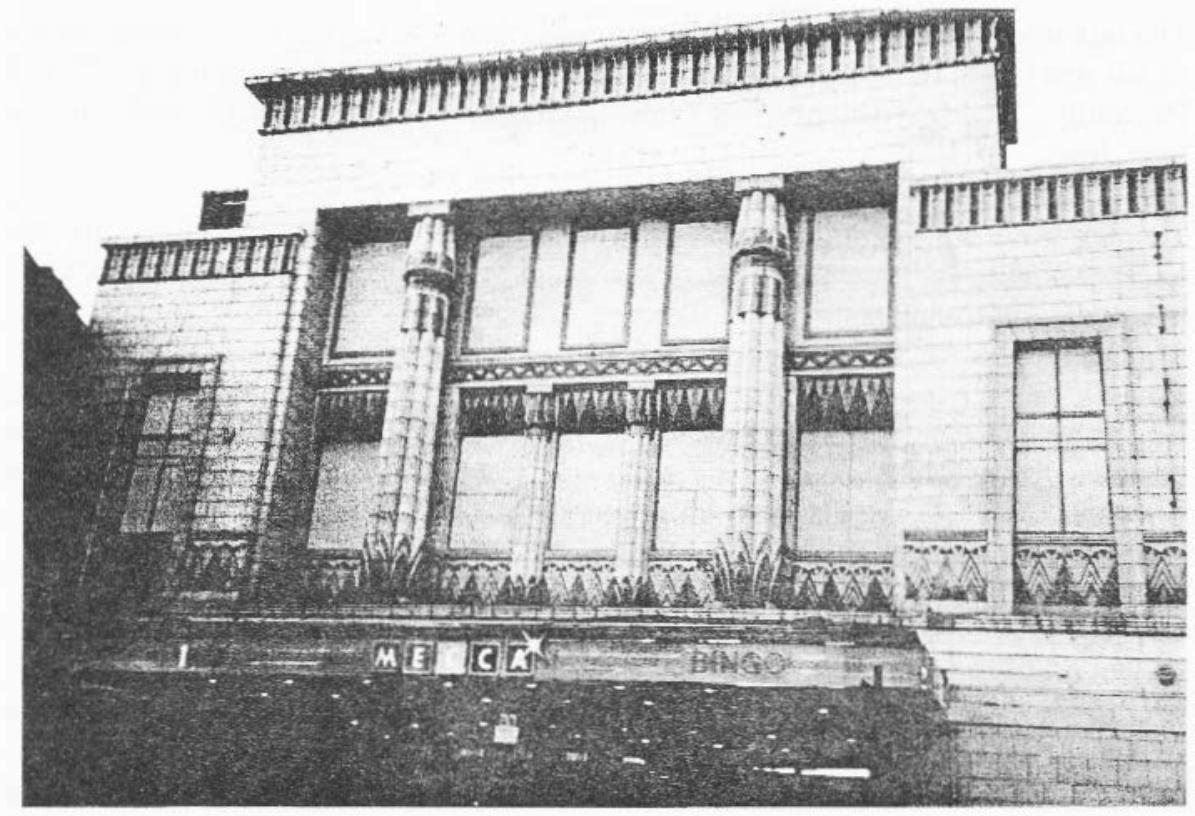

Figure 1. The old Carlion Cinema, an Art Deco Egyptianised structure, now housing the Mecca Secial Club on Essex Road in Islington. (Photo G. Tassie)

rior is totally lacking the Egyptianising influence that it once had. The facade of the building is typically Art Deco, with Egyptianising influences of brightly painted papyriform columns and two black cats flanking the entrance. This revealed the original function of the building, a cigarette factory, which made the Black Cat brand .

The next stop on the tour was the Degasas Building, a building that incorporates many elements derived from Ptolemaic temples, such as a prominently placed Pharaoh's head above the entrance. Before moving on to Kensal Creen Cemetery, a stop was made at MCDonald's on Bloomsbury Way to look at the Egyptianising motifs they have incorporated into their typical décor. 
On arrival at Kensal Green we were served lunch, before progressing around the cemetery, where many Egyptianising motifs could be seen on the various tombs, such as sphinxes, papyriform columns, pharaoh-heads, winged sun-discs, obelisks, stelac and ankh-signs. One of the jewels of the trip was saved to nearly last, the Mecca Bingo Hall on Essex Road, formerly the Carlton Cinema (fig. 1). Originally there were many Egyptianised cinemas in London, this is one of the last remaining, built in 193 in the Art Deco style. Although the interior still retains some of the original features, particularly the ceiling, much has now disappeared. However, the exterior of the building is covered in brightly covered tiling, showing much Eighteenth Dynasty Amarna influence, especially in the blank cartouches and columns that have elongated papyrus top.

The last stop on the tour was the Museum of London, to see the two rescued statues of Isis and Osiris from the façade of the Egyptian Hall that was originally at 170-173 Piccadilly. The two statues show Ptolemaic influence in their design, especially in their dress.

The day was not yet over, one more treat awaited the tour party - a visit to Croydon to see the "Ancient Egypt - Digging for Dreams" exhibition (http://w'w'collections. ucl.uk/diggingfordreams). The exhibition examines Egypt and its cultural impact, featuring highlights from the Petrie Muesum of Egyptian Archaeology's reserve collections, as well as a range of modem artef acts. This travelling exhibition is accompanied by many interesting events, aimed at both adults and children. The day was completed by a wine reception at the Croydon Clocktower, and a chance for all the delegates 10 mingle and discuss various aspects of Egyptology.

\section{December}

The papers discussed on the third day were divided into four sessions dealing with a variety of perspectives on ancient Egypt spanning both space and time. The first session began with Ancient Perspectives on Ancient Egypt. The discussion on ancient African perspectives examined how Egyptian iconography, architecture and religious elements were adopted into Meroitic seciety but took on roles different from their Egyptian counterparts. Contributors argued that because Egyptologists have carried out most of the investigations into Meroitic culture, the resultant perspective is of ten Egyptological rather than Sudanic. It was also pointed out that investigators have tended to overvalue the concept of the centralised state and consequently the inclination is to ignore or discount the role of other equally valid modes of subsistence.

In the discussion of Near Eastem perspectives on ancient Egypt participants raised questions concerning the hypothesis of Egyptian hegemony in this region at the end of the third millennium BC. A re-examination of archaeological evidence casts doubt on the assumption that the presence of Nile Valley Ware in the Southern Levant constitutes sufficient evidence for Egyptian military control of the region. It was suggested that scholars should re-examine the nature and extent of Egypt's influence in the Levant. The discussion of Greek perspectives of ancient Egypt addressed the interaction between Egyptians, Greeks and Macedonians as immigrants and concluded with the proposal for a more positive, interactive and egalitarian model for such socio-cultural relationships. Roman attitudes toward Egypt were examined via a first 
century AD Nilotic mosaic from Praeneste (Palestrina). A call was made for increased sensitivity to the range of views relating to the Roman depiction of the Egyptian scenes. In the section on Early Christian and Late Antique perspectives. the Christian appropriation of ancient Egyptian symbols such as the ankh and other Egyptian motifs used in Biblical art were considered. Discussants also examined the process of 'stereotype' appropriation by Egyptian priests in Late Antiquity who. based on textual evidence. appear to have token on the Roman view of Egypt and reenacted this foreign perception for their colonisers. For Medieval perspectives discussants highlighted the centuries of Egyptological work by medieval Arab scholars, thus dispelling the myth conceming early Muslim scholars and their purported lack of interest in ancient Egypt.

The second session dcalt with "Perspectives on Ancient Egypt Since Napoleon" including sections on the $19^{\text {th }}$ and $20^{\text {th }}$ centuries. Contributors for the session on "The Nineteenth Century" addressed the appropriation of Egyptian iconography for imperialistic purposes in the Egyptian W'ar of 1882 involving Britain and France. Participants also discussed the primary and secondary appropriation of obelisks and other Egyptian symbols in order to legitimise political, religious, and economic power. It was pointed out that the appropriator/borrower of such symbols may be ignorant of the original meaning. Discussants suggested that further investigation of the mechanism and definition of appropriation was necessary.

"The Twentieth Century" scision covered a wide range of topics including the extent of use and meaning of the term 'foreigner' in Egyptology. Discussants questioned why ancient Egypt holds such a high degree of fascination for modern society and why it figures largely in the archaeology of the disenfranchised. Concerns were also raised about why modern history has covered up the role of Africa in ancient Egypt. Also, a call was made for increased investigation of gender issues in ancient Egypt. Discussants encouraged investigators of every sub-field of Egyptology to employ increasingly self-reflexive methodologies in order to eliminate the localised and particularised 'mono-history' that continues to deny the socio-cultural diversity of ancient Egypt.

The first afternoon session was dedicated to "Egypt: Consumerism and the Visual and Performing Arts". In the confrontation of ancient Egypt with modern Egypt via tourism. discussants suggested that a more balanced view might be achieved by employing a greater number of qualified Egyptian guides. Discussants suggested that the incorporation of post-pharaonic Egyptian history and culture into tours may aid in dispelling the image of Egypt as an open-air museum. Participants also emphasised the need for scholars to increasingly consider archaeology and its dialectical relationship with current economic and political issues.

Perspectives concerning ancient Egypt in the visual and performing arts included views on the political nature of certain productions such as the opera Aida. One participant reported on a school class that re-enacted The Triumph of Horus as part of their ancient Egyptian history lesson. This session's discussions also included presentations about books, fashion and other interesting trends in Egyptomania. both within and outside modern Egypt. 
The final session of the conference was entitled Ancient Egy'pt: "Consumcrism. Representation and Film". This session included sections entitled "Representing Cleopatra and Ancient Egyptian Film". In the forner section, the discussion examined how Cleopatra VII represented herself as regent, mother, queen, diplomat and goddess in order to legitimise her clain to the throne, whilst the Romans represented her as a seductress. It was noted that despite the widespread tradition of Cleopatra in modern times, there is, ironically, no cultural tradition of Cleopatra in Egyptian history. The last section of the conference examined images of ancient Egypt on film. A product as well as a source of popular interest in the lives of ancient women, such as Cleopatra, portrayals from Hollywood are overwhelmingly characterised by the seductive Egyptian woman. Common themes included the oppositions of the 'good' woman vs. "bad' woman and false god vs. true god.

The day's stimulating discussions produced several main points. First, investigators must be vigilant in not excluding, delimiting and imposing 'realities' that are not there. Second, increased awareness is needed regarding the use and appropriation of Egyptian elements, how and why they are used, and why particular elements are reinvested with new meaning. Third, questions regarding Egyptian influences must distinguish primajy meanings associated with the production of material culture from secondary meanings attached to objects through their use and consumption. Finally. an important aspect of Egyptian or any culture is its organic nature; that is, one of constant flux, not only influencing but also receiving influences. The concept of a monolithic ancient Egypt is no longer tenable.

This innovative and thought-provoking conference concluded with a drinksreception at the Petrie Museum of Egyptian Archaeology. Professor Harry Smith introduced Professor Sir Christopher Lewellyn Smith, Provost and President of UCL, who gave a short speech expressing his support for the Petrie Museum and announced plans to re-house the Petrie Collection in The Panopticon, a new multistorey building to be built next to the Bloomsbury Theatre. 